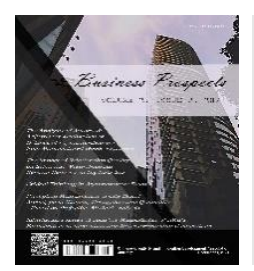

Business Prospects

Chinese Creativity and Innovation Development Association (CCIDA) journal homepage: www.ccidanpo.org

https://doi.org/10.52288/bp.27089851.2021.12.14

\title{
The Analysis and Comparison of the Comprehensive Index of the Development of China Urban Exhibition Industry
}

\author{
Jia-Ming Qiao ${ }^{1, *}$ \\ ${ }^{1}$ School of International Business, Xiamen University Tan Kah Kee College \\ * Correspondence: $1318118407 @$ qq.com
}

Received: 2021.06.07; Accepted: 2021.09.10; Published: 2021.12.01

\begin{abstract}
With the development of modern economy, exhibition industry has become an important platform for the construction of modern market system and open economic system. At present, there are many indicators to measure the competitiveness of urban exhibition industry in China. The annual index of competitiveness of Chinese city exhibition industry initiated by China convention and exhibition economic association has become the most authoritative report of competitiveness index of city exhibition industry. The exhibition industry is also one of the important evaluation criteria. This paper mainly uses the above two methods to calculate the exhibition competitiveness index of Chinese cities, and introduces the correlation coefficient to compare the stability of the ranking of the exhibition competitiveness index by the two methods. The study found that the correlation coefficient between the cities at the top and bottom of the ranking was large, that is, the ranking was relatively stable and barely changed. However, the ranking correlation coefficient of cities in the middle is smaller and the change is significant. However, the correlation coefficients of the cities ranked 21-40 are less than those of the top 20 cities, which also indicates that the abrupt change in the ranking of individual cities will affect the overall stability. Because of this, it shows that the evaluation indexes under different weights have a certain influence on the calculation of the comprehensive index of the city's exhibition competitiveness, and the AHP method can better reflect the advantages and disadvantages of the city's exhibition industry development.
\end{abstract}

Keywords: AHP; China's Urban Exhibition Industry Competitiveness Index; Evaluation Criteria; Rank of Composite Index Score; Correlation Coefficient

\section{Introduction}

Competitiveness refers to the ability of an actor to compete with other actors for certain resources, which can be a country, a region, an organization or an individual. In this paper, the author studies on city of the exhibition industry competitiveness refers to the specific to this particular industry exhibition business problem of regional competitiveness, city exhibition industry competitiveness refers to the system of regional social and economic structure, cultural values, policies and resources and environment under the action of multiple factors such as comprehensive, convention and exhibition industry at home and abroad exhibition on the market in a given area compared with other regions, with the optimal allocation of resources, and promote the development of exhibition industry overall and regional economic growth. The competitiveness of urban convention and exhibition industry is mainly determined by the competition performance of convention and exhibition industry, the internal resource conditions of convention and exhibition industry, and the external industry support of convention and exhibition industry. At the same time, it is also inseparable from the relevant environmental factors of convention and exhibition industry, such as the economic environment, political environment and natural environment of the city.

The Report on the Development of China's Exhibition Industry released by China Society of Exhibition Economy every year ranks the development level of the exhibition industry in various cities, but basically 
measures the development level of the city's exhibition industry from the perspectives of the number of exhibition halls, the area of exhibition halls and the number of exhibitions. This evaluation method has its reasonability, but it also has some shortcomings, such as the relatively single index selection and the failure to consider the relationship between the development level of the exhibition industry and the city itself.

In this paper, from a multidimensional perspective comprehensive development level evaluation system, try to establish exhibition organizers city exhibition organizers in China tries to explore the differences and similarities in the process of development. This article based on the existing literature and the conditions of the development of the exhibition organizers build a multi-index evaluation system, through the AHP method and the Chinese exhibition economy research institute's annual "China city exhibition industry competitiveness index" to evaluate the development level of city exhibition organizers, in order to achieve comprehensive development level difference and similarity analysis of city exhibition organizers research purpose.

\section{The Current Situation of China Urban Exhibition Industry}

As an important part of promoting exchanges and cooperation, China's exhibition industry has become an important platform for building a modern market system and an open economic system, playing an increasingly prominent role in China's economic and social development. Looking forward to 2020, the development of China's exhibition industry will present the following five development trends.

First, the domestic exhibition industry will maintain a steady growth trend. A number of well-known brand exhibitions with international influence, such as Canton Fair, Xiamen Trade Fair and Medical Fair, will continue to spring up, and the level of specialization, marketization and internationalization of the exhibition industry will continue to be improved. Secondly, an exhibition industry pattern of common regional development will gradually take shape. In 2018, China's exhibition industry will gradually form an exhibition pattern with the Beijing-Tianjin-Hebei, Yangtze River Delta and Pearl River Delta economic circles as the main three, and the second - and third-tier inland cities developing together. Third, countries and regions along the "The Belt and Road" will become important exhibition areas. Fourthly, the "Double-track Exhibition" mode will inject new vitality into the development of the exhibition industry. That carry out three media, exhibition and advertising industry cross-border integration, the offline events and large scene "reengineering" and staged, display and promotion on the Internet, the traditional "exhibition" and "meeting" two industry platform integration, on the Internet, digital exhibition industry to the production of new economic form. Fifth, the development of the exhibition industry will accelerate the deep integration with relevant industries. The value of the exhibition industry is mainly realized through the technology, specialization and commercialization of the exhibition, and the integration of its value chain is also based on the exhibition. Therefore, the exhibition industry can achieve industrial integration with other industries by focusing on marketing, experience and creativity. For example, by means of technology integration path, to achieve coordinated development of online and offline exhibition; With the help of digital technology, the cities enhance the sense of customer experience and improve the display technology.

The year 2020 will be a fruitful year for China's efforts to complete the building of a moderately prosperous society in all respects and the 13th Five-Year Plan. In general, the national strategy of 202 will have a more obvious impact on the development of the exhibition industry, especially the joint "The Belt and Road" initiative and international production capacity cooperation. No matter going abroad to participate in exhibitions or hold exhibitions abroad, they may enjoy the new opportunities brought by the "the Belt and Road" initiative. At the same time, the overall development trend of the national exhibition industry will slow down in 2020, and the exhibition industry will transition from quantitative expansion to a new stage of quality improvement. In terms of domestic policies, new developments in the field of science and technology will also bring new opportunities to the exhibition industry. For example, new technologies such as Internet, AI, VR, and blockchain are widely used in medical, industrial, entertainment, mobile terminals and other fields, which greatly expand the space of theme selection for the exhibition industry. In addition, the cross-border integration of exhibition facilities, exhibition industry, exhibition and data information continue to develop in depth, injecting new momentum into the high-quality development of the exhibition industry. In addition, with the upgrading of people's consumption, exhibitions focusing on medical care for the elderly, elderly care, exclusive leisure and cultural tourism are likely to become a hot field in China's exhibition industry in the future (Chen, 2020).

However, there are still some problems in the development of the exhibition industry in China. For example, the development of the exhibition industry in cities is uneven, and there are many indicators related to the exhibition industry, and the indicators to evaluate the development level of the exhibition industry in different 
places are not uniform. The decisive role of market in the allocation of exhibition resources is not strong, and the unclear property rights restrict the flow of exhibition elements. There are blind spots in the business environment, and the intellectual property rights of exhibitors and organizers cannot be effectively protected; Lack of mandatory environmental protection standards in the exhibition industry (Chen, 2008; Zhao, 2016). Therefore, in the future, practical measures should be taken to reduce formalism, respect the free choice of exhibitors and buyers, give full play to the decisive role of market in resource allocation, ensure policy neutrality, create a fair competition environment, and protect the intellectual property rights of exhibitors and organizers. In the urban development competitiveness of convention and exhibition, in 2018 China's urban convention and exhibition industry competitiveness index, according to data from the study of Shanghai, Beijing, Guangzhou, Chengdu, Shenzhen and other cities in 2019 "the most competitive exhibition cities in China (municipality directly under the central government and the deputy provincial city)", Changsha, Zhengzhou, Suzhou, Kunming, Hefei and other cities have been selected as "China's Most Competitive Convention and Exhibition Cities (provincial capitals and prefecture-level cities)" in 2019. Guided by the comprehensive reflection of the overall environmental competitiveness of the city, the professional competitiveness of the city's exhibition industry, the competitiveness of the city's exhibition education and the service competitiveness of the city's exhibition authorities, the index builds multi-level related indicators. Finally, it will form a comprehensive representation of the development level and development potential of China's urban exhibition industry, including 130 cities in China (China Society of Convention and Exhibition Economics (2014-2019); Chengdu Expo Bureau, 2018; Jiang, 2019).

This article takes the Chinese exhibition economy research institute released "2019 China exhibition data statistics report" in the data as the basis, through the Chinese exhibition economy research institute to develop a unified KPI calculation method and the analytic hierarchy process (AHP), finally obtained the development of the city's annual exhibition organizers composite index, in order to measure the exhibition industry competitiveness of each city. The comparison of the two results is made to analyze the ranking and other changes of the exhibition competitiveness of each city.

\section{The Description of Research Methodology}

\subsection{The Accounting Method of KPI of China Society of Convention and Exhibition Economics}

In order to objectively interpret the development status of the exhibition industry in each city, based on the exhibition statistics data of 13 dimensions for the development of the exhibition industry in each city, a unified KPI accounting method is developed, and finally the comprehensive index of the development of the exhibition industry in each city in the current year is obtained. (China Society of Convention and Exhibition Economics, 2013-2019)

The evaluation indexes of China's urban exhibition industry development comprehensive index in 2019 are as follows:

(1) Number of City Exhibitions: 0.1 points for each exhibition;

(2) Urban Exhibition Area: 0.1 points per 10,000 square meters of exhibition space;

(3) The number of exhibition subjects within the city: 0.1 points for each domestic self-hosted exhibition subject;

(4) The number of overseas self-sponsored exhibitions hosted by the institutions in the city: 0.1 points for each overseas self-hosted exhibition project, and 1 point for each overseas self-hosted exhibition subject;

(5) Number of exhibition venues in the city: 0.1 points per pavilion;

(6) The indoor exhibition area available for exhibition in the city exhibition venue: 0.1 points per 10,000 square meters;

(7) Competent government departments and institutions of urban exhibition industry: 0.1 points for each competent government department and professional organization;

(8) Urban UFI membership and certification programs: 1 point for each UFI member unit and 1 point for each certification project;

(9) Urban IAEE Membership and Certification Program: 1 point for each IAEE unit member and 0.1 points for each individual member;

(10) The exhibition area of urban exhibition projects is listed in the number of TOP100 in 2019: 1 point for each exhibition project;

(11) The number of urban exhibition projects listed in the TOP3 in 2019 by industry breakdown: 1 point for each exhibition project; 
(12) The number of exhibition majors in urban colleges and universities: 0.3 points for each undergraduate institution and 0.2 points for a junior college;

(13) The number of listed companies in the city exhibition industry: 2 points for each listed company in the exhibition industry

\subsection{AHP Comprehensive Evaluation Index System of Competitiveness of Chinese City Exhibition Industry}

On the basis of analyzing the construction path of urban exhibition industry competitiveness, according to the principle of feasibility, representativeness and hierarchy of quantitative index selection of analytic hierarchy process (AHP), This paper constructs a multi-level comprehensive evaluation index system from four dimensions and manifestations of the scale, performance, development environment and growth ability of the urban exhibition industry, as shown in Table 1.

Table 1. List of weights of each indicator.

\begin{tabular}{|c|c|c|c|c|c|}
\hline $\begin{array}{c}\text { Criterion } \\
\text { Layer }\end{array}$ & Weight & Element Layer & Weight & Index Level & Weight \\
\hline \multirow{2}{*}{$\begin{array}{l}\text { Scale of } \\
\text { Exhibition } \\
\text { Industry }\end{array}$} & \multirow[b]{2}{*}{0.2319} & $\begin{array}{c}\text { Convention and Exhibition } \\
\text { Venues }\end{array}$ & 0.5714 & $\begin{array}{l}\text { Number of Pavilions } \\
\text { The Exhibition Area }\end{array}$ & $\begin{array}{l}0.3876 \\
0.6124\end{array}$ \\
\hline & & $\begin{array}{c}\text { Convention and Exhibition } \\
\text { Company and Related } \\
\text { Personnel } \\
\end{array}$ & 0.4286 & $\begin{array}{c}\text { Public Company } \\
\text { Members of the IAEE } \\
\text { IAEE Individual Member }\end{array}$ & $\begin{array}{l}0.4090 \\
0.2576 \\
0.3334\end{array}$ \\
\hline \multirow[b]{2}{*}{$\begin{array}{l}\text { Exhibition } \\
\text { Industry } \\
\text { Performance }\end{array}$} & \multirow[b]{2}{*}{0.5662} & The Scale of the Exhibition & 0.7159 & $\begin{array}{l}\text { Number of Exhibitions } \\
\text { The Total Exhibition Area }\end{array}$ & $\begin{array}{l}0.7597 \\
0.2403\end{array}$ \\
\hline & & The Quality of the Exhibition & 0.2841 & $\begin{array}{c}\text { UFI Members } \\
\text { UFI Certification Programs } \\
\text { TOP3 Projects } \\
\text { TOP100 Projects } \\
\end{array}$ & $\begin{array}{l}0.2970 \\
0.1634 \\
0.2698 \\
0.2698 \\
\end{array}$ \\
\hline \multirow[t]{2}{*}{$\begin{array}{l}\text { Industrial } \\
\text { Development } \\
\text { Environment }\end{array}$} & \multirow[t]{2}{*}{0.1210} & Industry Environment & 0.4970 & $\begin{array}{c}\text { The Main Body of the } \\
\text { Domestic Exhibition } \\
\text { Number of Overseas } \\
\text { Exhibitions } \\
\text { Overseas Exhibition Subjects }\end{array}$ & $\begin{array}{l}0.7425 \\
0.1233 \\
0.1342\end{array}$ \\
\hline & & The Political Environment & 0.5030 & Government Authorities & 0.5030 \\
\hline $\begin{array}{l}\text { Industry } \\
\text { Growth } \\
\text { Capacity }\end{array}$ & 0.0809 & Industry Growth Support & 0.0809 & $\begin{array}{l}\text { Undergraduate Institutions } \\
\text { Colleges and Universities }\end{array}$ & $\begin{array}{l}0.6895 \\
0.3150\end{array}$ \\
\hline
\end{tabular}

Source: The authors, April 2021

After further analysis of the factor layer, 17 evaluation indexes are selected to construct the comprehensive evaluation index system of the competitiveness of urban exhibition industry, which consists of target layer, criterion layer, element layer and index layer. The comprehensive evaluation index system is divided into four levels: the first level is the target level, that is, the comprehensive evaluation index system of the competitiveness of the city exhibition industry. The second layer is the criterion layer, including the scale of the exhibition industry, the performance of the exhibition industry, the development environment of the industry and the growth ability of the industry. The third layer is the factor layer, which is a subdivision of the criterion layer. The scale of the exhibition industry includes the same exhibition venues, exhibition enterprises and exhibition practitioners. Exhibition industry performance includes exhibition scale, exhibition quality and exhibition benefit; Industrial development environment includes political and industrial environment, economic environment and urban environment. The ability of industrial growth includes the ability of driving industry, the strength of supporting industry growth and the degree of openness. The fourth layer is the index layer, including a total of 17 indicators.

\section{The Analysis of Urban Exhibition Industry Development Difference and Similarity}

The annual comprehensive index ranking of the development of the exhibition industry of each city was 
finally obtained through the unified KPI accounting method and analytic hierarchy process developed by China Association of Exhibition Economy. The ranking results take the top 20 cities of the two methods as examples, shown in Table 2 and Table 3.

Table 2. Ranking of China's urban exhibition industry development comprehensive index in 2019 (Top20).

\begin{tabular}{|c|c|c|c|c|c|c|c|c|c|c|c|c|c|c|c|c|c|c|c|}
\hline \multirow[t]{2}{*}{ NO. } & \multirow[t]{2}{*}{ City } & \multicolumn{17}{|c|}{ Comprehensive Index of the Development of the City's Annual Exhibition } & \multirow{2}{*}{$\begin{array}{l}\text { Composite } \\
\text { Index Score }\end{array}$} \\
\hline & & 1 & 2 & 3 & 4 & 5 & 6 & 7 & 8 & 9 & 10 & 11 & 12 & 13 & 14 & 15 & 16 & 17 & \\
\hline 1 & Shanghai & 502 & 1718.5 & 352 & 1 & 1 & 9 & 98 & 7 & 12 & 70 & 27 & 22 & 79 & 39 & 8 & 14 & 3 & כנ \\
\hline 2 & Beijing & 223 & 589.8 & 334 & 1 & 1 & 8 & 33 & 7 & 10 & 97 & 30 & 10 & 34 & 4 & 7 & 11 & 8 & .98 \\
\hline 3 & Guangzhou & 242 & 1024 & 159 & - & - & 5 & 49 & 4 & 3 & 13 & 15 & 11 & 33 & 14 & 9 & 14 & 1 & 44.8 \\
\hline 4 & Shenzhen & 101 & 395 & 31 & - & - & 2 & 61 & 2 & 2 & 36 & 13 & 12 & 22 & 3 & - & - & 2 & 151.2 \\
\hline 5 & Chengdu & 246 & 385.2 & 15 & - & - & 3 & 33 & 4 & - & - & 9 & 9 & 21 & 5 & 9 & 7 & - & 116.72 \\
\hline 6 & Chongqing & 147 & 339.9 & 86 & - & - & 3 & 31 & 3 & 1 & 9 & 2 & 1 & 14 & 6 & 4 & 6 & - & 39 \\
\hline 7 & Qingdao & 147 & 300.2 & 85 & - & - & 3 & 45 & 2 & 2 & 8 & 4 & 3 & 15 & 1 & - & 3 & - & 91.82 \\
\hline 8 & Nanking & 276 & 298.5 & 79 & - & - & 4 & 16 & 4 & - & - & 6 & 3 & 9 & - & 1 & 3 & - & 86.65 \\
\hline 9 & Xiamen & 104 & 240 & 58 & - & - & 1 & 40 & 2 & 4 & 15 & 1 & 2 & 13 & 3 & 2 & 3 & - & 83.7 \\
\hline 10 & Changsha & 262 & 309.8 & 82 & - & - & 4 & 9 & 6 & - & - & 3 & 2 & 6 & 3 & 4 & 4 & - & 83.28 \\
\hline 11 & Zhengzhou & 240 & 301.1 & 113 & - & - & 3 & 33 & 4 & - & - & 3 & 1 & 6 & - & 4 & 7 & - & 82.01 \\
\hline 12 & Jinan & 100 & 277.1 & 63 & - & - & 3 & 21 & 3 & - & - & 7 & 14 & 7 & 1 & 4 & 5 & - & 91 \\
\hline 13 & Wuhan & 168 & 256.8 & 51 & - & - & 4 & 22 & 6 & - & - & 4 & 3 & 9 & 2 & 7 & 8 & 2 & 76.48 \\
\hline 14 & Hangzhou & 57 & 148.3 & 57 & - & - & 7 & 31 & 10 & 2 & 4 & 5 & 18 & 2 & 2 & 5 & 5 & 2 & 70.53 \\
\hline 15 & Kunming & 131 & 304.8 & 37 & - & - & 5 & 72 & 1 & - & - & - & - & 6 & 2 & 3 & 4 & 1 & 66.78 \\
\hline 16 & Tianjin & 64 & 168.3 & 34 & - & - & 4 & 50 & 3 & 1 & 8 & - & 4 & 8 & 4 & 5 & 10 & 2 & 64.83 \\
\hline 17 & Hefei & 218 & 220.1 & 54 & - & - & 1 & 13 & 2 & - & - & 2 & - & 7 & - & 2 & 6 & - & 61.61 \\
\hline 18 & Shenyang & 159 & 228.7 & 52 & - & - & 2 & 13 & 4 & - & - & 2 & 1 & 6 & 1 & 1 & 3 & - & 56.77 \\
\hline 19 & Linyi & 115 & 221.9 & 42 & - & - & 7 & 18 & 3 & - & - & 2 & 2 & 10 & 1 & - & - & - & 55.69 \\
\hline 20 & Changchun & 145 & 205.7 & 67 & - & - & 5 & 23 & 4 & - & - & - & - & 2 & 1 & 4 & 2 & - & 49.57 \\
\hline
\end{tabular}

Source: China Society of Convention and Exhibition Economics (2013-2019)

Comprehensive Index: 1. Number of exhibitions; 2. Total exhibition area; 3. Domestic Exhibition Organizers; 4. The number of overseas exhibitions; 5. Overseas exhibition subjects; 6. Number of pavilions; 7. Pavilion area; 8. Competent governmental bodies; 9. Member of IAEE; 10. IAEE Individual Member; 11. Member of UFI; 12. UFI certification program; 13. Top 3 projects in the industry; 14. Top100 project of single exhibition area; 15. Undergraduate institutions; 16. Colleges and universities; 17. Public companies.

Table 3. Ranking of AHP Exhibition Competitiveness Index in 2019 (Top 20).

\begin{tabular}{|c|c|c|c|c|c|c|c|c|c|c|c|c|c|c|c|c|c|c|c|}
\hline \multirow[t]{2}{*}{ Number } & \multirow[t]{2}{*}{ City } & \multicolumn{17}{|c|}{$\begin{array}{l}\text { Comprehensive Index of AHP Comprehensive Evaluation Index System of } \\
\text { Chinese City Exhibition Industry }\end{array}$} & \multirow{2}{*}{$\begin{array}{c}\text { Exhibition } \\
\text { Competitiveness } \\
\text { Index }\end{array}$} \\
\hline & & 1 & 2 & 3 & 4 & 5 & 6 & 7 & 8 & 9 & 10 & 11 & 12 & 13 & 14 & 15 & 16 & 17 & \\
\hline 1 & Shanghai & 9 & 98 & 3 & 12 & 70 & 502 & $1,718.5$ & 27 & 22 & 79 & 39 & 352 & 1 & 1 & 7 & 8 & 14 & 969 \\
\hline 2 & Guan & 5 & 49 & 1 & 3 & 13 & 242 & 1024 & 15 & 11 & 33 & 14 & 159 & - & - & 4 & 9 & 14 & 152 \\
\hline 3 & Beijing & 8 & 33 & 8 & 10 & 97 & 223 & 589.8 & 30 & 10 & 34 & 4 & 334 & 1 & 1 & 7 & 7 & 11 & 574 \\
\hline 4 & Chengdu & 3 & 33 & - & - & - & 246 & 385.2 & 9 & 9 & 21 & 5 & 15 & - & - & 4 & 9 & 7 & 146.7718 \\
\hline 5 & Shenzhen & 2 & 61 & 2 & 2 & 36 & 101 & 395 & 13 & 12 & 22 & 3 & 31 & - & - & 2 & - & - & 1009 \\
\hline 6 & Changsha & 4 & 9 & - & - & - & 262 & 309.8 & 3 & 2 & 6 & 3 & 82 & - & - & 6 & 4 & 4 & 962 \\
\hline 7 & nanking & 4 & 16 & - & - & - & 276 & 298.5 & 6 & 3 & 9 & - & 79 & - & - & 4 & 1 & 3 & 124.6377 \\
\hline 8 & Chongqing & 3 & 31 & - & 1 & 9 & 147 & 339.9 & 2 & 1 & 14 & 6 & 86 & - & - & 3 & 4 & 6 & 5595 \\
\hline 9 & Zhengzhou & 3 & 33 & - & - & - & 240 & 301.1 & 3 & 1 & 6 & - & 113 & - & - & 4 & 4 & 7 & 582 \\
\hline 10 & Qingdao & 3 & 45 & - & 2 & 8 & 147 & 300.2 & 4 & 3 & 15 & 1 & 8 & - & - & 2 & - & 3 & 111 \\
\hline 11 & Kunming & 5 & 72 & 1 & - & - & 131 & 304.8 & - & - & 6 & 2 & 37 & - & - & 1 & 3 & 4 & 586 \\
\hline 12 & Wuhan & 4 & 22 & 2 & - & - & 168 & 256.8 & 4 & 3 & 9 & 2 & 51 & - & - & 6 & 7 & 8 & 100.2035 \\
\hline 13 & Jinan & 3 & 21 & - & - & - & 100 & 277.1 & 7 & 14 & 7 & 1 & 63 & - & - & 3 & 4 & 5 & 98.74526 \\
\hline 14 & Hefei & 1 & 13 & - & - & - & 218 & 220.1 & 2 & - & 7 & - & 54 & - & - & 2 & 2 & 6 & 93.28163 \\
\hline
\end{tabular}


Table 3. Ranking of AHP Exhibition Competitiveness Index in 2019 (Top 20) (Cont.).

\begin{tabular}{cccccccccccccccccccccc}
\hline \multirow{2}{*}{ Number } & \multirow{1}{*}{ City } & \multicolumn{10}{c}{ Comprehensive Index of AHP Comprehensive Evaluation Index System of $\begin{array}{c}\text { Exhibition } \\
\text { Competitiveness }\end{array}$} \\
\cline { 3 - 4 } & & 1 & 2 & 3 & 4 & 5 & 6 & 7 & 8 & 9 & 10 & 11 & 12 & 13 & 14 & 15 & 16 & 17 & Index \\
\hline 15 & Xiamen & 1 & 40 & - & 4 & 15 & 104 & 240 & 1 & 2 & 13 & 3 & 58 & - & - & 2 & 2 & 3 & 89.64619 \\
16 & Shenyang & 2 & 13 & - & - & - & 159 & 228.7 & 2 & 1 & 6 & 1 & 52 & - & - & 4 & 1 & 3 & 89.1783 \\
17 & Linyi & 7 & 18 & - & - & - & 115 & 221.9 & 2 & 2 & 10 & 1 & 42 & - & - & 3 & - & - & 82.48111 \\
18 & Changchun & 5 & 23 & - & - & - & 145 & 205.7 & - & - & 2 & 1 & 67 & - & - & 4 & 4 & 2 & 82.34517 \\
19 & Tianjin & 4 & 50 & 2 & 1 & 8 & 64 & 168.3 & - & 4 & 8 & 4 & 34 & - & - & 3 & 5 & 10 & 64.03383 \\
20 & Ningbo & 1 & 6 & - & - & - & 99 & 163.3 & 2 & 3 & 4 & 1 & 25 & - & - & 4 & 1 & 1 & 61.36399 \\
\hline
\end{tabular}

Source: The authors, April 2021

Comprehensive Index: 1. Number of exhibitions; 2. Total exhibition area; 3. Public companies; 4. Member of IAEE; 5. IAEE Individual Member; 6. Number of pavilions; 7. Pavilion area; 8. Member of UFI; 9. UFI certification program; 10. Top 3 projects in the industry; 11 . Top100 project of single exhibition area; 12. Domestic Exhibition Organizers; 13. The number of overseas exhibitions; 14. Overseas exhibition subjects; 15. Competent governmental bodies; 16. Undergraduate institutions; 17. Colleges and universities.

\subsection{The Analysis of Urban Exhibition Industry Development Difference}

On the multi-index level, the relative advantages and disadvantages of the urban indicators indicate that the development of urban exhibition industry is similar. According to the combination similarity, the similarity matrix of the development of the exhibition industry between cities can be obtained. The higher the combination similarity, the closer the development mode of the exhibition industry between cities.

In this paper, the correlation analysis between the top 60 and bottom 60 in the KPI method and the ranking results obtained in the AHP method was conducted for 20 groups respectively. The correlation coefficients of the three groups are shown in Table 4 and 5.

As can be seen from Table 4, in terms of ranking, the highest correlation coefficient of the top 20 is 0.8735 . The correlation coefficient of 41-60 was the next, which was 0.8204 . The correlation coefficient of 21-40 was the lowest, which was 0.7796 . The correlation coefficients of the next 60 places in Table 5 decreased in turn. From this phenomenon, it can be inferred that the ranking of urban exhibition competitiveness in the order before and after the two evaluation methods presents a high correlation coefficient, that is, the ranking is not affected by the evaluation method, while the middle sequence is greatly affected, and the correlation coefficient is not stable.

Table 4. Correlation analysis of the top 60.

\begin{tabular}{ccc|cc|cc}
\hline & \multicolumn{2}{c}{$1-20$} & \multicolumn{2}{c}{$21-40$} & \multicolumn{2}{c}{$41-60$} \\
& AHP & KPI & AHP & KPI & AHP & KPI \\
\hline AHP & 1 & & 1 & & 1 & 1 \\
KPI & 0.8735 & 1 & 0.7796 & 1 & 0.8204 & 1 \\
\hline
\end{tabular}

Source: The authors, April 2021

Table 5. Correlation analysis of the bottom 60.

\begin{tabular}{ccc|cc|cc}
\hline & \multicolumn{1}{c}{$178-187$} & \multicolumn{2}{c}{$158-177$} & \multicolumn{2}{c}{$138-157$} \\
& AHP & KPI & AHP & KPI & AHP & KPI \\
\hline AHP & 1 & & 1 & & 1 & 1 \\
KPI & 0.7343 & 1 & 0.6338 & 1 & 0.2089 & 1 \\
\hline
\end{tabular}

Source: The authors, April 2021

By comparing the correlation coefficients of the top 60 and the bottom 60, it can be found that although the correlation coefficients of the two are high, the coefficient of the top is still greater than that of the bottom, which indicates that the change degree of the exhibition competitiveness of the top cities is less than that of the bottom in the two evaluation methods. 
Normally, the correlation coefficient of the first 60 positions should also decrease from front to back, but the deviation of 21-40 positions is smaller than the correlation coefficient of the adjacent 20 positions before and after, which is only 0.7796 . Therefore, this paper also observed the difference of the ranking of the top 60 cities under the two evaluation criteria, and the results were shown in Table 6.

Through the observation of the ranking changes of the cities ranked from 21 to 40 and the other two parts, it can be concluded that the range of change of most cities is basically the same while the range of change of a few cities is larger. Therefore, we speculated that the small correlation coefficient might be due to the large changes in the ranking of some cities. For example, Sanya dropped 28 places in the AHP standard and Zhuhai dropped 19 places. Therefore, it can be judged that the ranking of comprehensive competition index of China's urban exhibition industry has changed under the two evaluation methods.

This also reflects that China Society of Exhibition Economy has covered up the disadvantages of the exhibition industry in some cities to a certain extent based on the unified KPI accounting method for the development of the exhibition industry in various cities. Such as Sanya's MICE tourism products homogenization phenomenon is more serious, and degree of marketization exhibition external environment to be improved. What's more, its development heavy hardware light software, the lack of development and management personnel, the lack of technical supporting services. The scale of Zhuhai's convention and exhibition industry is also inadequate. Due to the decline of its economic status, only the biennial Zhuhai Airshow can be retained. Moreover, compared with other cities, Zhuhai's convention and exhibition industry is short of projects, facilities and talents. The different weights of the method of analytic hierarchy process can reflect the shortcomings of these cities in exhibition development.

Table 6. Ranking of the top 60 cities under the two evaluation criteria.

\begin{tabular}{|c|c|c|c|c|c|c|c|c|c|c|c|}
\hline City & KPI & AHP & $\begin{array}{l}\text { Ranking } \\
\text { Changes }\end{array}$ & City & KPI & AHP & $\begin{array}{l}\text { Ranking } \\
\text { Changes }\end{array}$ & City & KPI & AHP & $\begin{array}{l}\text { Ranking } \\
\text { Changes }\end{array}$ \\
\hline Shanghai & 1 & 1 & 0 & Sian & 21 & 26 & 5 & Urumchi & 41 & 34 & -7 \\
\hline Beijing & 2 & 3 & 1 & Suzhou & 22 & 23 & 1 & Hohhot & 42 & 35 & -7 \\
\hline Guangzhou & 3 & 2 & -1 & Ningbo & 23 & 20 & -3 & Foshan & 43 & 48 & 5 \\
\hline Shenzhen & 4 & 5 & 1 & Dalian & 24 & 22 & -2 & Shijiazhuang & 44 & 38 & -6 \\
\hline Chengdu & 5 & 4 & -1 & Taiyuan & 25 & 25 & 0 & Zibo & 45 & 41 & -4 \\
\hline Chongqing & 6 & 8 & 2 & Fuzhou & 26 & 24 & -2 & Xining & 46 & 52 & 6 \\
\hline Qingdao & 7 & 10 & 3 & Guiyang & 27 & 32 & 5 & Guilin & 47 & 44 & -3 \\
\hline Nanking & 8 & 7 & -1 & Nanchang & 28 & 30 & 2 & Weifang & 48 & 47 & -1 \\
\hline Xiamen & 9 & 15 & 6 & Wuxi & 29 & 27 & -2 & Xuzhou & 49 & 46 & -3 \\
\hline Changsha & 10 & 6 & -4 & Langfang & 30 & 40 & 10 & Kunshan & 50 & 42 & -8 \\
\hline Zhengzhou & 11 & 9 & -2 & Jinhua & 31 & 28 & -3 & Yantai & 51 & 45 & -6 \\
\hline Jinan & 12 & 13 & 1 & Nanning & 32 & 29 & -3 & Salt City & 52 & 54 & 2 \\
\hline Wuhan & 13 & 12 & -1 & Haikou & 33 & 39 & 6 & Yinchuan & 53 & 53 & 0 \\
\hline Hangzhou & 14 & 21 & 7 & Wenzhou & 34 & 36 & 2 & Taizhou & 54 & 55 & 1 \\
\hline Kunming & 15 & 11 & -4 & Dongguan & 35 & 31 & -4 & Tangshan & 55 & 61 & 6 \\
\hline Tianjin & 16 & 19 & 3 & Zhongshan & 36 & 33 & -3 & Nantong & 56 & 51 & -5 \\
\hline Hefei & 17 & 14 & -3 & Harbin & 37 & 43 & 6 & Taizhou & 57 & 56 & -1 \\
\hline Shenyang & 18 & 16 & -2 & Zhuhai & 38 & 57 & 19 & The River & 58 & 49 & -9 \\
\hline Linyi & 19 & 17 & -2 & Lanzhou & 39 & 37 & -2 & Luoyang & 59 & 63 & 4 \\
\hline Changchun & 20 & 18 & -2 & Sanya & 40 & 68 & 28 & Jiaxing & 60 & 58 & -2 \\
\hline
\end{tabular}

Source: The authors, April 2021

\subsection{The Analysis of Urban Exhibition Industry Development Similarity}

The development of urban exhibition industry in China shows a trend of gradient decline from coastal to inland, which is roughly similar to the development pattern of urban economic level in China, indicating that the development level of urban exhibition industry is closely related to the development of urban economy. It can be found from Table 7 that some cities with similar levels of development have the same number of changes in their rankings under AHP, such as Jinjiang, Linxia and Sanming as well as Zhaoqing, Wuchang and Quzhou.

In addition, the most striking is that the development level of the exhibition organizers in some western cities is relatively high, while the development level of the exhibition organizers in central China is generally 
concentrated in the rear of the city. Therefore, through the adjustment of industrial structure as well as the level of exhibition, promote the development of exhibition organizers in central cities, play a role in the cohesion of exhibition organizers in central cities in China's development, it will become an important way to the development of exhibition economy.

Table 7. Ranking of the bottom 40 cities under the two evaluation criteria.

\begin{tabular}{|c|c|c|c|c|c|c|c|}
\hline City & KPI & AHP & $\begin{array}{l}\text { Ranking } \\
\text { changes }\end{array}$ & City & KPI & AHP & $\begin{array}{l}\text { Ranking } \\
\text { changes }\end{array}$ \\
\hline Chaoyang & 148 & 146 & -2 & Fushun & 168 & 167 & -1 \\
\hline Yuhuan & 149 & 121 & -28 & Nongan County & 169 & 150 & -19 \\
\hline Ganzhou & 150 & 142 & -8 & Qitaihe & 170 & 151 & -19 \\
\hline Liangshan & 151 & 122 & -29 & Huludao & 171 & 175 & 4 \\
\hline Kashi & 152 & 110 & -42 & Songyuan & 172 & 177 & 5 \\
\hline Guangan & 153 & 129 & -24 & Bazhong & 173 & 178 & 5 \\
\hline Jilin & 154 & 184 & 30 & Shiyan & 174 & 161 & -13 \\
\hline Qianjiang & 155 & 145 & -10 & Taicang & 175 & 180 & 5 \\
\hline Panzhihua & 156 & 143 & -13 & Nanan & 176 & 164 & -12 \\
\hline Nanchong & 157 & 144 & -13 & Dingzhou & 177 & 169 & -8 \\
\hline Chengde & 158 & 170 & 12 & Jinjiang & 178 & 171 & -7 \\
\hline Dezhou & 159 & 168 & 9 & Linxia & 179 & 172 & -7 \\
\hline Yingkou & 160 & 158 & -2 & Sanming & 180 & 173 & -7 \\
\hline Qiqihar & 161 & 174 & 13 & Liaoyang & 181 & 176 & -5 \\
\hline Longyan & 162 & 141 & -21 & Tonghua & 182 & 179 & -3 \\
\hline Meihekou & 163 & 157 & -6 & Zhaoqing & 183 & 181 & -2 \\
\hline Daqing & 164 & 185 & 21 & Wuchang & 184 & 182 & -2 \\
\hline Daqing & 165 & 163 & -2 & Quzhou & 185 & 183 & -2 \\
\hline Ganzi & 166 & 165 & -1 & Dongyang & 186 & 186 & 0 \\
\hline Zhuji & 167 & 166 & -1 & Huangnan & 187 & 187 & 0 \\
\hline
\end{tabular}

Source: The authors, April 2021

\section{Conclusion}

In this paper, the analytic hierarchy process (AHP) is used to study the competitiveness index of China's urban exhibition industry. Combined with the unified method of China's exhibition economy research, the comprehensive index of the development of exhibition organizers in each city is compared by KPI calculation method, which can be regarded as a useful attempt to study the competitiveness ranking of urban exhibition industry. The competitiveness evaluation index system of urban exhibition industry constructed by AHP is scientific and practical, and can reflect the strengths and weaknesses of the development of the measured urban exhibition industry.

Therefore, this paper puts forward the following suggestions: First, each city should implement different development strategies according to the differentiation level of the development of the exhibition industry to promote the healthy development of China's exhibition industry. For the cities with high level of development of the exhibition industry, it is necessary to integrate regional resource elements, give play to the spillover effect of the core exhibition cities, and lead the overall development of the regional exhibition industry from point to area. For the cities with better development of the exhibition industry, it is necessary to maintain the current development trend, strengthen the performance evaluation of the exhibition projects, cultivate or introduce highquality exhibition projects, realize the fine management of the development of the exhibition industry, and comprehensively improve the development quality of the exhibition industry. For the cities in the initial development stage of exhibition industry, the exhibition organizers should focus on further speeding up economic restructuring and the development of foreign trade, playing the role of the management institution in order to realize the exhibition market operation of the project, improving the economic benefits of show business. If the location and resources under the condition of congenital disadvantage cannot be changed, the government should enhance the service efficiency of supply, give policy bonus to attract exhibition talents, develop characteristic exhibitions according to local conditions, and inject vitality into urban consumption.

Second, cities should draw on each other's strengths to promote coordinated development of China's 
exhibition industry according to the degree of similarity in the development of their exhibition industries. First, cities of the same type can learn from each other and improve the development level of their own exhibition industry by comparing and analyzing each other's successful cases and management models. Secondly, within the region, cities with different development modes should learn from each other and comprehensively enhance the activity of the regional exhibition market through market sharing and mutual recommendation to promote the formation of industrial clusters within the region.

\section{References}

1. Chen, L. (2020). China Council for the Promotion of International Trade (CCPIT) Released the China Exhibition Economic Development Report. Nanning Evening News.

2. China Council for the Promotion of International Trade. China Exhibition Economic Development Report.

3. Chu, X. H. (2009). Research on the Competitiveness of Urban Exhibition Industry in China.

4. Chen, Y. L. (2008). Problems and Countermeasures in the Development of China's Exhibition Industry. Theory of Science, 10: 32-33.

5. Li, H. M. (2016). Construction of Competitiveness Evaluation Index System of Urban Exhibition Industry. Journal of Luoyang Normal University, 5: 78-82.

6. Li, Y. H. (2010). Research on Comprehensive Evaluation of the Competitiveness of Urban Exhibition Industry.

7. Li, M., Wang, D. Z., \& Hu, X. L. (2007). Study on the Competitiveness Evaluation of China's Urban Exhibition Industry. Contemporary Economics, 14: 66-67.

8. Ma, Y., \& Chen, H. Y. (2013). Study on the Construction of Comprehensive Evaluation Index System of China's Urban Exhibition Industry Competitiveness Based on AHP. Tourism Research, 1: 1-6.

9. Wu, Z. Y. (2020). Research on the Competitiveness of Urban Exhibition Industry and Its Promotion.

10. Yu, W., \& Niu, Y. H. (2012). An Empirical Study on the Competitiveness of Urban Exhibition Industry-A Case Study of Beijing, Shanghai and Guangzhou. Journal of Jiangsu Commerce, 12: 78-81.

11. Zhao, F. S. (2016). Research on the Development Status and Countermeasures of China's Exhibition Industry under the New Normal (Unpublished Ph.D Dissertation). Beijing: University of Chinese Academy of Social Sciences.

12. Zhao, T. W. (2009). Construction of Exhibition Industry Competitiveness Analysis Index System and Evaluation Model. International Business Technology, 3: 40-43.

(Editor: Yuxin Ke) 